\title{
衛星画像を用いた干ばつ指標の開発 DEVELOPMENT OF DROUGHT INDEX USING SATELLITE IMAGES
}

\author{
濱田 準哉 1 • 乃田 啓吾2 ・ 木口 雅司 ${ }^{3}$ ・沖 一雄 ${ }^{4} \cdot$ Somchai BAIMOUNG $^{5}$ ・

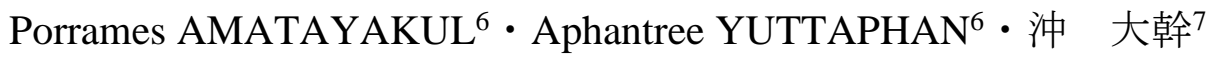 \\ Junya HAMADA, Keigo NODA, Masashi KIGUCHI, Kazuo OKI, Somchai BAIMOUNG, \\ Porrames AMATAYAKUL and Aphantree YUTTAPHAN, Taikan OKI \\ 1学生会員 東京大学大学院工学系研究科社会基盤学専攻 修士課程学生（†113-8656 東京都文京区本郷 \\ 7-3-1) \\ 2非会員 博士（農学） 東京大学生産技術研究所（干153-8505 東京都目黒区駒場4-6-1） \\ 3正会員 博士（理学） 東京大学生産技術研究所（干153-8505 東京都目黒区駒場4-6-1） \\ 4非会員 博士（都市・地域計画） 東京大学生産技術研究所（于153-8505 東京都目黒区駒場4-6-1） \\ 5 非会員 博士（工学） Ministry of Information and Communication Technology（120 Moo 3, 6-9 floor The \\ Government Complex Commemorating His Majesty Chaeng Watthana Road, Thung Song Hong, Khet Laksi \\ Bangkok 10210 Thailand) \\ 6非会員 Thai Meteorological Department（4353 Sukhumvit Road, Bangna, Bangkok 10260 Thailand) \\ 7 正会員 博士（工学） 東京大学生産技術研究所（†153-8505 東京都目黒区駒場4-6-1）
}

\begin{abstract}
Droughts cause severe human and economic damage and appropriate drought monitoring is important to reduce damage. Drought indices are one of the effective methods for drought monitoring. Drought indices which can evaluate drought spatially are required for detailed drought monitoring. The objective of this study was to develop a drought index, SDT (Standardized Difference Temperature), and show the usefulness of SDT. SDT focuses on the diurnal range of land surface temperature, using satellite images for spatial evaluation. SPI (Standardized Precipitation Index) was used to evaluate the usefulness of SDT. The results showed that SDT and SPI have good correlation in the beginning of the dry season and that SDT is valid for drought monitoring in these periods.
\end{abstract}

Key Words : drought index, satellite images, diurnal range of land surface temperature, Standardized Precipitation Index, north Thailand

\section{1. 背景}

国際連合食糧農業機関（FAO）の推定では，干ばつは 毎年60〜80億ドルの被害を引き起こしており，1900年以 降，1100万人が死亡し，20億人以上が影響を受けている ことからも，非常に多数の人々に影響を与える災害であ ると言える，気候変動により今後，干ばつの頻度，影響 度および期間は増大し, 人的・経済的被害も拡大すると 推測される。干ばつに対応し，被害を軽減するためには， 適切な干ばつモニタリングが必要となる。

干ばつの察知・現状把握・分析の手法の一つとして, 干ばつ指標（Drought Index）が用いられる。WMO (1992) によって干ばつ指標は「長期的でかつ異常な水 不足の積算結果に関する指標」と定義されるが，異常な 水不足の定義は地域毎に異なるため, 個々の地域の気候
条件を考慮することが極めて重要である，例えば，降水 量の少ない乾燥地帯では，水不足が連続して発生してい るが，干ばつの深刻度は必ずしも大きくない. なぜなら， 降水量が少量である地域では，それに適応した生態系や 社会システムが既に形成されているためである.干ばつ 指標には，時間偏差や累積状況を考慮し，個々の地域の 気候条件を反映した干ばつの評価を行うことが必要であ る.

代表的な干ばつ指標として，SPI（Standardized Precipitation Index）があげられる.SPIは降水量だけで表 現される干ばつ指標であり, 気象台等の降水量観測デー タを使用して簡単に算出することができる.また標準化 により，時間偏差の考慮を行い，個々の地域の気候条件 を反映するとともに，容易に地域間を比較することを可 能にしている.SPIの他にも広く使用されている干ばつ 指標は多数存在するが，多くの干ばつ指標はSPI と同様 
に空間的に不連続な地上観測データを使用するため，数 值化できる場所は限定され，空間偏差の評価が不十分で あると言える.

従って，より詳細な干ばつモニタリングのためには, 干ばつの面的な評価が可能であることが求められる. 本 研究では，衛星画像を使用することで，面的に干ばつを 評価することを目指す，具体的には，地表面温度の昼夜 の差に着目することで，面的評価が可能な干ばつ指標を 提案し，その有用性を示すことを目的とする.

\section{2. 昼夜の地表面温度差に着目した干ばつ指標の}

\section{提案}

\section{(1) SPIの概要}

新たな干ばつ指標の定式化において，既存の干ばつ指 標であるSPIを参照した．SPIは以下の式で表される.

$$
S P I=\left(X_{i j}-\overline{X_{i j k}}\right) / \sigma_{i j k}
$$

$X_{i j}=\mathrm{i}$ 地点における $\mathrm{j}$ 月日の降水量

$\overline{X_{i j k}}=\mathrm{i}$ 地点における $\mathrm{j}$ 月日の降水量の $\mathrm{k}$ 年間の平均

$\sigma_{i j k}=\mathrm{i}$ 地点における $\mathrm{j}$ 月日の降水量の $\mathrm{k}$ 年間の標準偏差

SPIの主な特徵は，降水量だけで表されているため簡 単に算出できることと，標準化しているため異なる場所 と比較可能なことである. Sergio M, Vicente-Serrrano ${ }^{1)}$ このSPIの特徴を活かし, 多くの地域の干ばつの程度を まとめて評価している。 またSPIは值が正であるほど湿 潤傾向，負であるほど渇水傾向であることを示している

\section{（2）提案する干ばつ指標の概要}

本研究で提案するSDT (Standardized Difference Temperature）は，地表面温度の昼夜の差を使用して， SPI 同様の定式化を行った. SDTは以下の式で表され る.

$$
S D T=\left(\Delta T_{i j}-\overline{\Delta T_{i j k}}\right) / \sigma_{i j k}
$$

$\Delta T_{i j}=\mathrm{i}$ 地点における $\mathrm{j}$ 月日の昼と夜の地表面温度差

$\overline{\Delta T_{i j k}}=\mathrm{i}$ 地点における $\mathrm{j}$ 月日の昼と夜の地表面温度差の $\mathrm{k}$ 年 間の平均

$\sigma_{i j k}=\mathrm{i}$ 地点における $\mathrm{j}$ 月日の昼と夜の地表面温度差の $\mathrm{k}$ 年

間の標準偏差

SDTは昼夜の地表面温度差のみで表現されることが特 徵である. 昼夜の地表面温度差によって土壌水分量の大
小を間接的に表し，干ばつの程度を評価する. SDTの值 が正に大きいほど，昼夜の地表面温度差は大きく，土壤 水分量が少量であることを意味し，干ばつの程度は大き いと考えられる，逆にSDTの值が負に大きい場合は，昼 夜の地表面温度差は小さく, 土畩水分が多量であること を示唆し, 干ばつの程度は小さいと推定できる. Inge Sandholt et al. ${ }^{2} や Z$ Wan et al. ${ }^{3}{ }^{3}$ は地表面温度と土畩水分量 や干ばつの関係性の評価を行っている。しかしながら， 地表面温度の昼夜の差には着目していない. また衛星を 用いた土畩水分量の計測は，土地利用の違いによる影響 を大きく受けるため, 様々な土地利用が混在する広域の 干ばつ評価には適さない. そのため本研究では土壤水分 量ではなく，地表面温度の昼夜の差を指標として用いた。

SDTの利点は3つ挙げられる．1つ目は地表面温度の データは衛星から取得するため, あらゆる場所で数值化 でき，面的な評価が可能なことである．2つ目は算出が 容易であること，3つ目は標準化しているため異なる場 所の值と比較可能なことが挙げられ，これらは同様の定 式化を行ったSPIの特徴と共通している. 一方で, 対象 期間中に土地利用が変わった場合，昼夜の地表面温度差 の平均值に変化が生じ，正確な評価ができないことが懸 念される.

\section{3. 研究手法}

\section{（1）対象地域}

図-1に示す北部タイの10都市（Mae Hong Son, Chiang Rai, Mae Sariang, Chiang Mai, Lampang, Nan, Uttaradit, Mae Sot, Phitsanulok, Phetchabun) を対象とする. タイ では干ばつの発生が問題となっており, タイの干ばつに 関する研究は数多く存在する.

また北部タイでは，他の地域と同様に農業が盛んであ り，干ばつの被害は農作物の生産量に大きな影響を与え る. 特に稲作を行う農家が多く, かつタイは世界有数の コメの輸出国であるため, 干ばつによりタイのコメの生 産量が大幅に減少した場合，その影響は世界各地に波及 する，よってタイは干ばつ被害を評価する上で，非常に 重要な地域であると言える.

\section{(2) SDTの算出}

本研究では, 地表面温度はTerra/MODIS（Moderate Resolution Imaging Spectrometer) のデータを使用し，そ

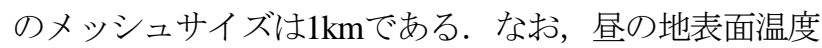
は10:30に，夜の地表面温度は22:30に観測されている. 図-2は2011年4月1日〜2011年4月10日におけるタイ周辺 での地表面温度の昼夜の差の空間分布図である.2002年 〜2011年の10年分の地表面温度のデータを使用してSDT を算出した。 


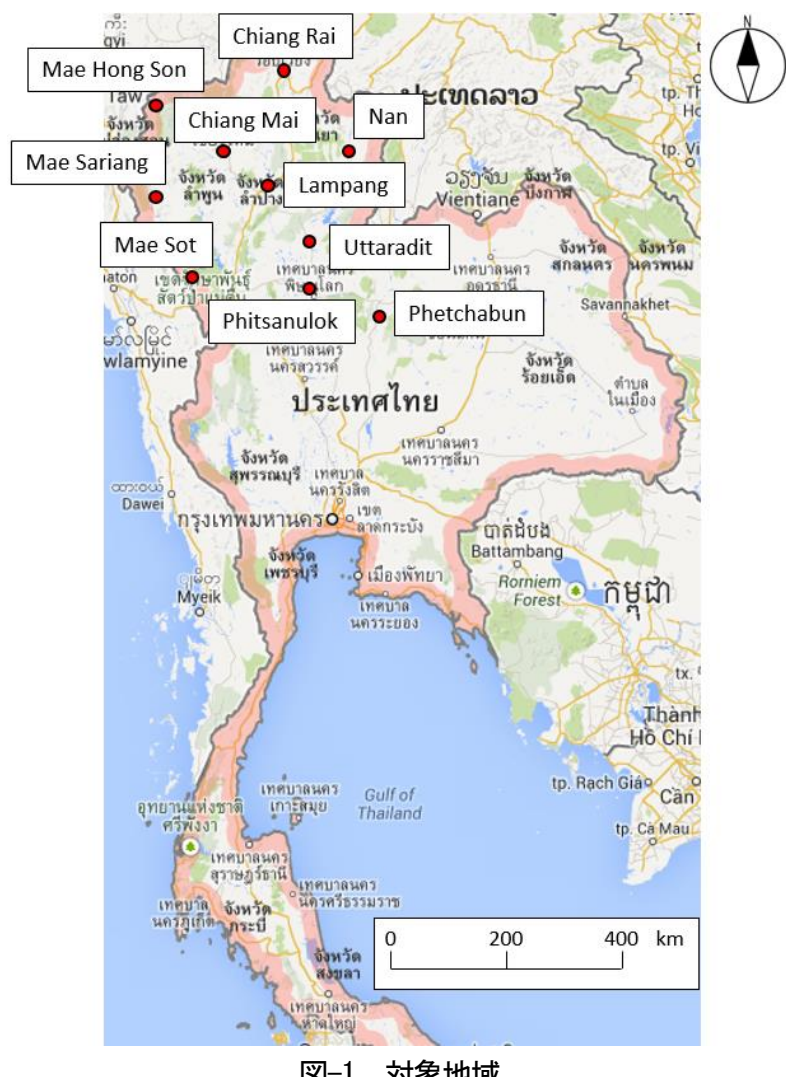

図-1 対象地域

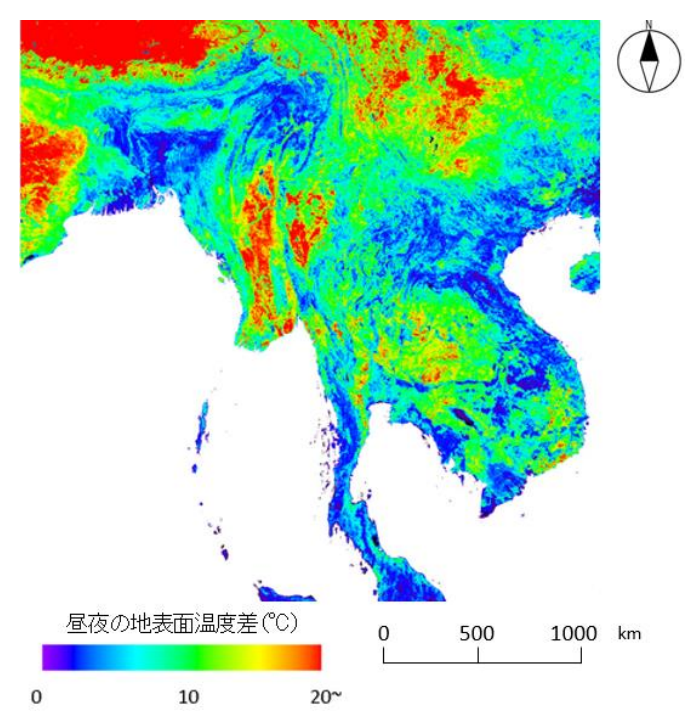

図-2 昼夜の地表面温度差の空間分布

本研究で用いた具体的なSDT值の計算方法は以下の通 りである．例えば4月のSDTを求める場合は，1日毎の SDTを算出し，その值を1力月間で平均する，4月1日を 例とすると，1日毎のSDTは， $\Delta T_{i j}$ を地点における4月 1 日の地表面温度差, $\overline{\Delta T_{i j k}}$ をi地点における4月 1 日の地 表面温度差の2002年から2011年の平均值, $\sigma_{i j k}$ をi地点 における4月1日の地表面温度差の2002年から2011年の標 準偏差として, 上記の式より求める. 以下では, 4月1ヶ
月間のSDTを4月SDTと表記する。

\section{（3）検証方法}

本研究では，干ばつ指標としてSDTが有効であること を示すために, SPIとの関係性を評価する. Kalyanee et al. ${ }^{4}$ は，SPIを使用したタイの干ばつモニタリングを行い, SPIがタイの農作物の生産量の増減をうまく表している ことを明らかにした。また白岩ら ${ }^{5}$ は過去20年間の稲生 産統計および降雨データを使用して，タイにおいて降水 量が稲作の生産変動を左右することを示した. このよう にタイではSPIや降水量によって農作物の生産量が説明 できることが先行研究から判明している，そこで，本研 究ではSPIとの関係性を検証することで，SDTが干ばつ を表すことを示す。

SPIの值による干ばつの程度の区分に関しては C.T.Agnew ${ }^{6}$ が提示するものなど複数の分類方法が存在 寸るが，本研究ではU.S. Drought Monitor standardが使用 している干ばつの深刻さの分類を参考とした（表-1）. SPIの算出にはタイ国気象局による2002年から2011年の 日別降水量計測值を使用した。比較に用いるSDTは, SPIの算出に使用される降水量を測定している気象台が 含まれるピクセルの值とした.

\section{(4) 対象時期}

本研究の対象時期は4月と11月とした。北部タイの気 候は雨季と乾季に二分され，4月と11月はそれぞれ雨季 の始まりと乾季の始まりに該当する．本研究ではその雨 季の始まりと乾季の始まりに対するSDTの適用可能性を 評価する. 以下に本研究で対象時期として雨季の始まり と乾季の始まりを選択した具体的な理由を挙げる.

まず気候的要因が挙げられる. タイにおいて降水量の 大小の影響が最も顕著である時期は，雨季と乾季の境界 であると言える. 図-3に1951年〜2011年の10都市の降水 量データの月毎の平均值および標準偏差を, 表-2に各月 の変動係数をそれぞれ示す. 乾季は月降水量が $0 \mathrm{~mm} の$ 場 合も数多く存在し，多量の降水量は期待されていない. そのため少量の降水量に適応した社会システムが形成さ れており，降水量が不十分であることによる干ばつの被 害は小さい. 雨季は十分な降水量が確保されているため, 例年と比較して降水量が不足した場合であっても干ばつ 被害は発生しにくい. また雨季は月降水量の変動係数が

表-1 SPI 值を用いた干ばつの分類

\begin{tabular}{|l|l|}
\hline \multicolumn{1}{|c|}{ Description } & \multicolumn{1}{c|}{ SPI value } \\
\hline No drought & -0.5 and above \\
\hline Abnormally dry & -0.5 to -0.7 \\
\hline Moderate drought & -0.8 to -1.2 \\
\hline Extreme drought & -1.3 to -1.5 \\
\hline Severe drought & -1.6 to -1.9 \\
\hline Exceptional drought & -2.0 or less \\
\hline
\end{tabular}




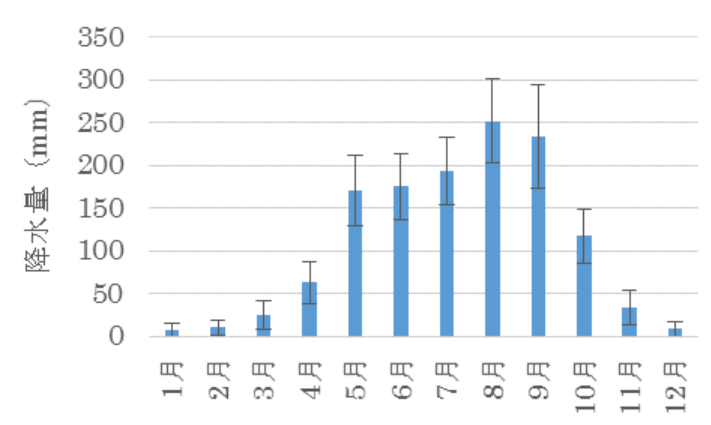

図-3 対象地域における月降水量の平均値と標準偏差

表-2 対象地域における月降水量の変動係数

\begin{tabular}{|l|l|l|l|l|l|}
\hline 1月 & 2月 & 3月 & 4月 & 5月 & 6月 \\
\hline 1.05 & 0.83 & 0.65 & 0.38 & 0.24 & 0.22 \\
\hline
\end{tabular}

\begin{tabular}{|l|l|l|l|l|l|}
\hline 7月 & 8月 & 9月 & 10月 & 11月 & 12月 \\
\hline 0.21 & 0.19 & 0.26 & 0.27 & 0.58 & 0.97 \\
\hline
\end{tabular}

小さく，降水量の大小の影響が小さい.

次に農業的要因が挙げられる. 白岩ら5゙はタイの稲作 において，雨季では植え付け期から生育前期に当たる雨 季前半において降水量と生産量平年偏差に正の相関が見 られる地域の存在を示し，乾季では乾季作付け期間前の 降水量と生産量に直接的な関係を示寸地域が存在するこ とを明らかにした．雨季の始まりと乾季の始まりはそれ ぞれ上記の雨季作の植え付け期から生育前期と乾季作付 け期間前に該当し，この期間における干ばつの程度が生 産量と結びつくことが示唆されている.

\section{4. 結果および考察}

\section{（1）4月におけるSDTの有用性の検討}

4月SDTと比較検討寸るSPIの期間として1ヶ月（4月 $\mathrm{SPI}) ， 2$ 个月（3月4月SPI），3个月（2月3月4月SPI）を 候補とする．例えば，3月4月SPIは3月1日〜4月30日の降 水量データを使用してSPIを算出したものである. 3月4 月SPI 2月 3 月 4 月SPIのように, SDT計測時期以前の降 水量を含めて考慮することで，降水がSDTに与える影響 にタイムラグが生じる可能性を検討した. 4月SDTと4月 $\mathrm{SPI}$ ３月4月SPI，2月3月4月SPIのそれぞれの相関係数を 表-3に示寸.

表-3より4月SDTと3月4月SPIの相関が最も高いことが わかる. 同月1ヶ月の降水量よりも前月から 2 ケ間の降 水累積状況が4月SDT，つまり4月における昼夜の地表面 温度差と関連が大きいことがわかる。また2月の降水量 は極めて少量であるため，2月3月4月SPIと3月4月SPIの 值がほぼ等しくなり，その結果2月3月4月SPIの相関が, 3月4月SPIと同様に比較的高い值となった.
ここでは, 最も相関が高い4月SDTと3月4月SPIの関係 を評価する. 図-4は対象地域における2002年〜2011年の 4月SDTを示している.また図-5は対象地域における 2002年〜2011年の3月4月SPIを示している．4月SDT・3 月4月SPIともに，10地点において共通する傾向が年毎に 見られる一方で, 各地点で差異が多少存在することがわ かる. また渴水年や洪水年がはっきりとわかれているこ とが確認できる.

表-3 各SPI と 4 月 SDT との相関係数

\begin{tabular}{|r|r|r|}
\hline \multicolumn{1}{|c|}{ 4月SPI } & 3月4月SPI & 2月3月4月SPI \\
\hline-0.38 & -0.55 & -0.53 \\
\hline
\end{tabular}

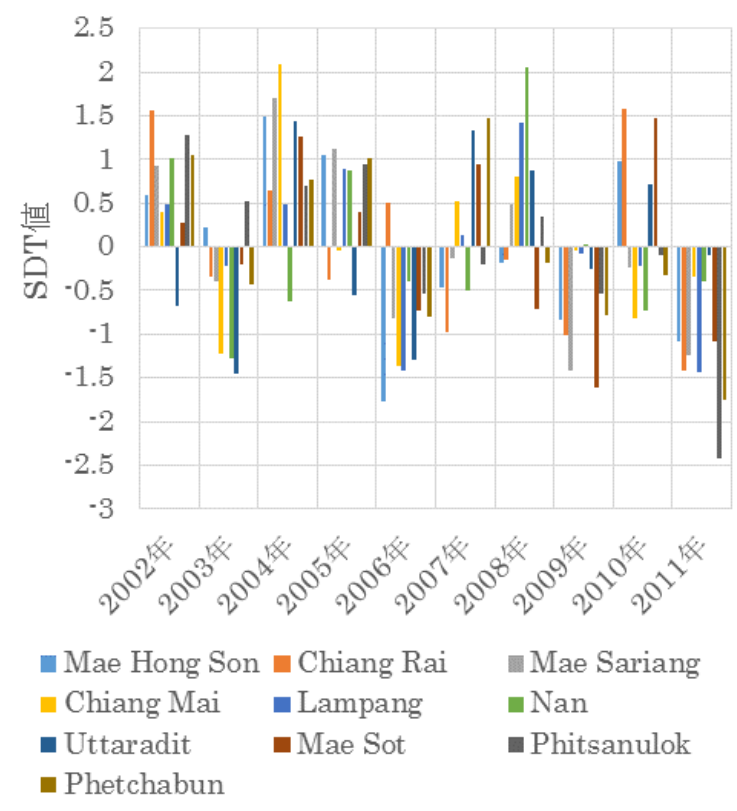

図-4 対象地域における 2002 年 2011 年の 4 月 SDT
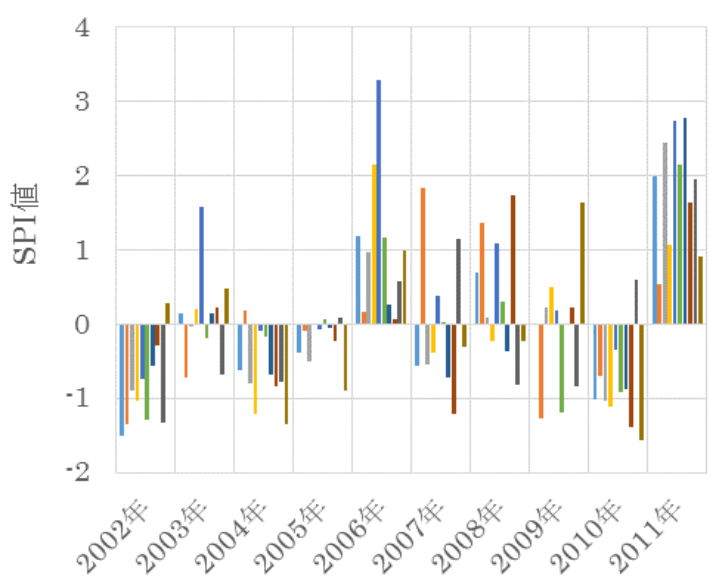

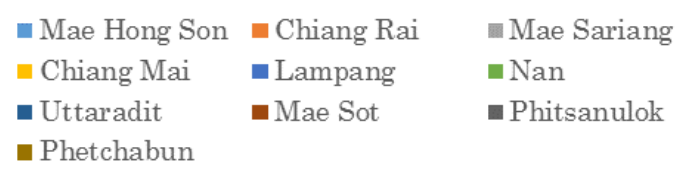

図-5対象地域における 2002 年〜2011 年の 3 月 4 月 SPI 


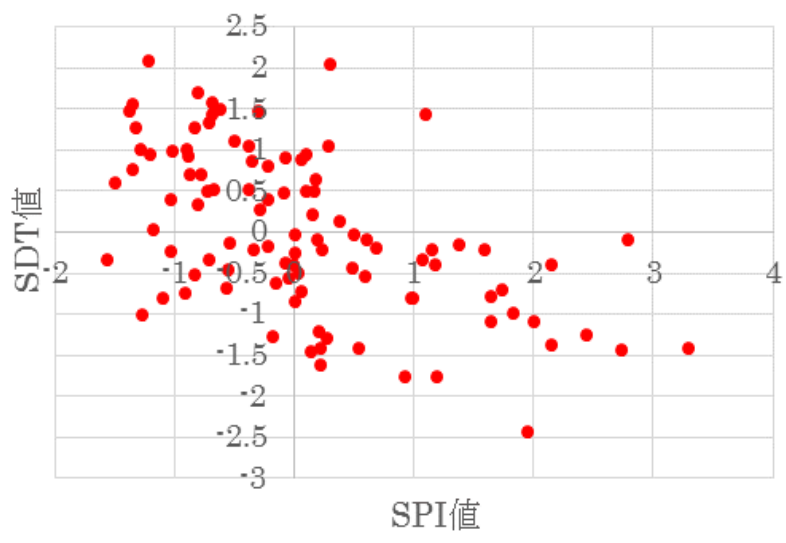

図-6 4 月 SDT と 3 月 4 月 SPI の関係

図-6に4月SDTと3月4月SPIの関係を示寸。4月SDTと3 月4月SPIは負の相関（相関係数：-0.55）を示し，相関係 数は有意水準 $1 \%$ を満たす。 4 月SDT と 3 月 4 月SPIが負の 相関を示寸ことは仮説と合致している．しかしながら， 表-1で乾燥状態と定義される-0.5以下では4月SDTと 3 月 4 月SPIの相関は低く，分布にばらつきがある．そのため4 月においては，SDTは干ばつ指標として有用ではないと 結論付けられる.

\section{（2）11月におけるSDTの有用性の検討}

11月SDTと比較検討寸るSPIの期間として，4月の場合 と同様に，1ヶ月（11月SPI），2ヶ月（10月11月SPI）， 3ケ月（9月10月11月SPI）を候補とする。11月SDTと11 月SPI，10月 11 月SPI，9月10月11月SPIのそれぞれの相関 係数を表-4に示す.

表-4より11月SDTと10月11月SPIが最も相関が高いこ とがわかる。これは，11月の月降水量より10月から2ヶ 月間の累積降雨の方が，11月SDTと深く関連しているこ とを表している。また9月の降水量が10月11月と比較し て多いため，9月10月11月SPIの值に10月と11月の降水量 の大小が反映されにくくなったことが，9月10月11月SPI の相関が低くなった理由であると考えられる.

ここでは，最も相関が高い11月SDTと10月11月SPIの 関係を評価する．図-7は対象地域における2002年〜2011 年の11月SDTを示している。.また図-8は対象地域におけ る2002年〜2011年の10月11月SPIを示している.

11 月SDT と 10 月 11 月 SPIの関係を図-9に示す。11月 $\mathrm{SDT}$ と 10月 11 月SPIは負の相関を示し，相関係数は-0.46 である。この相関係数は有意水準 $1 \%$ を満たす。 11 月 SDTと10月11月SPIが負の相関を示すことは仮説と一致 している．特に，10月11月SPIの值が，表-1で乾燥状態 と定義される-0.5以下では11月SDT と10月 11 月SPIの相関 が高く，-0.5以上では相関が低いことがわかる．SDTに よる評価が必要とされるのは，降水量が不十分な場合で あり，SPIの值が-0.5以下において相関が高いことは望ま しい結果であり，SPIの值が-0.5以上において相関が低い
ことは実用上問題ではない，と考えられる.したがって, 雨季の終わりである11月においてSDTが干ばつ指標とし て有効であると解釈できる.

また図-9にPhitsanulokにおける2002年〜2011年の11月 $\mathrm{SDT}$ と10月11月SPIの関係を示した。11月SDTと10月11

表-4 各 SPI と 11 月 SDT との相関係数

\begin{tabular}{|r|r|r|}
\hline \multicolumn{1}{|c|}{ 11月SPI } & 10月11月SPI & 9月10月11月SPI \\
\hline-0.42 & -0.46 & -0.34 \\
\hline
\end{tabular}

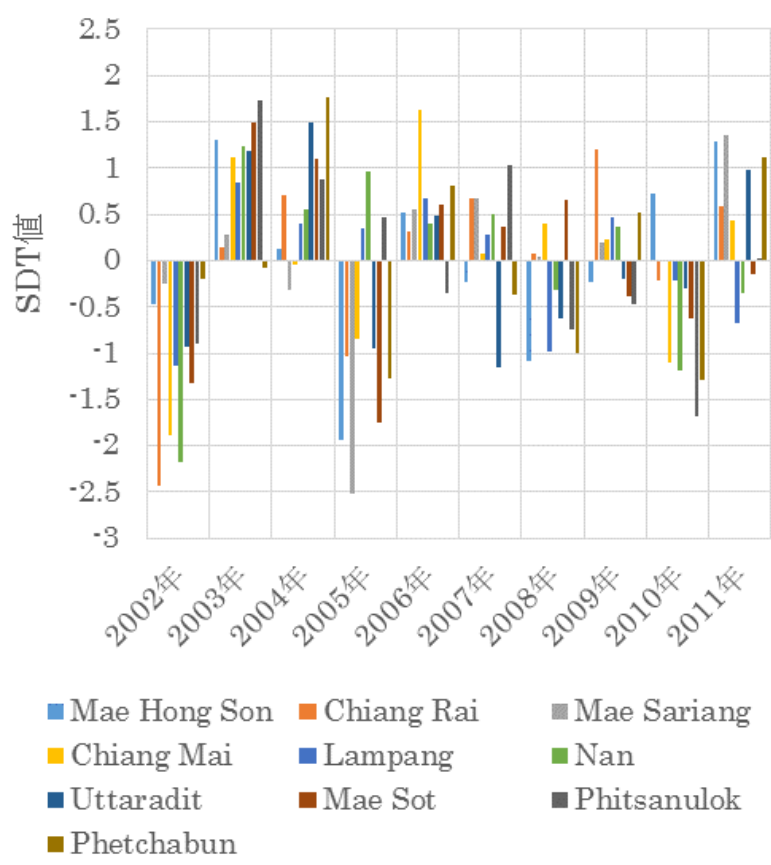

図-7 対象地域における 2002 年〜2011 年の 11 月 SDT

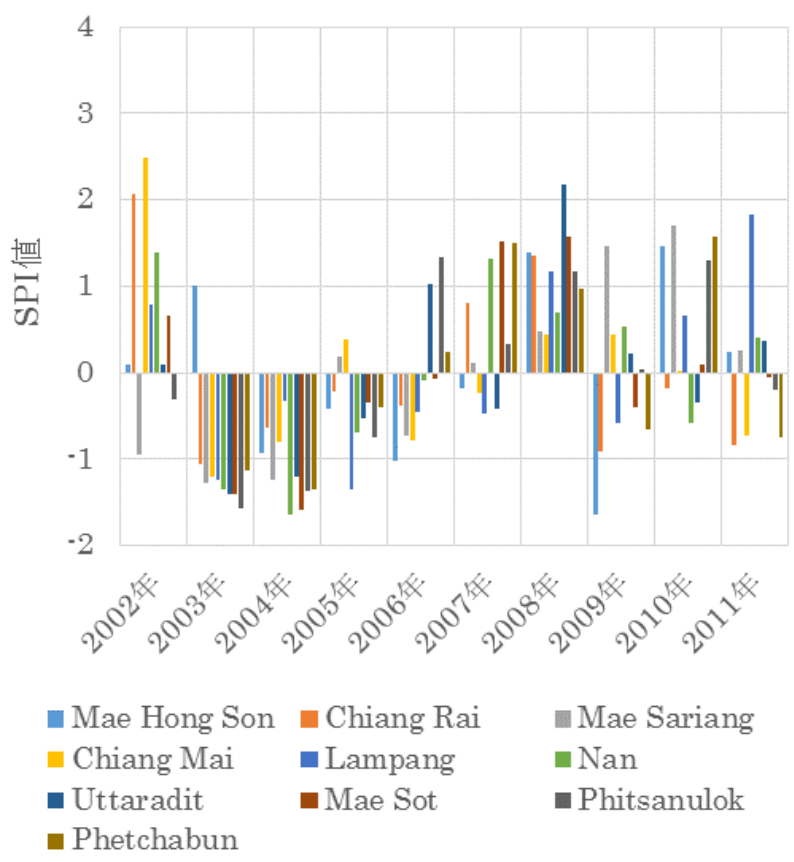

図-8 対象地域における 2002 年〜2011 年の 10 月 11 月 SPI 


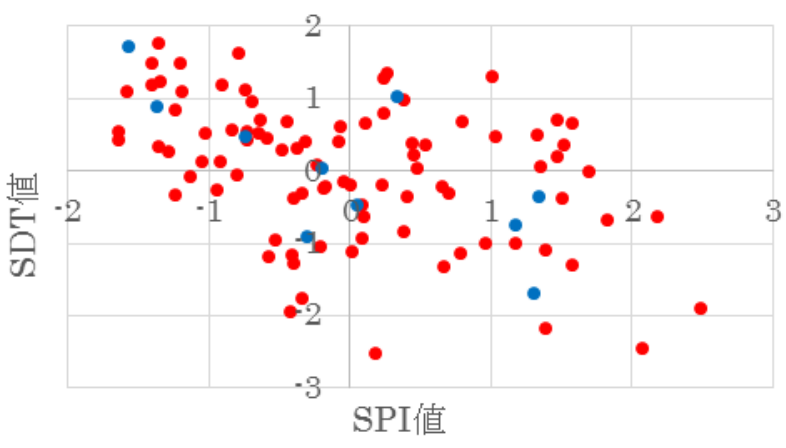

- Phitsanulok以外の9都市 - Phitsanulok

図-9 11 月 SDT と 10 月 11 月 SPI の関係

$2004 / 11$

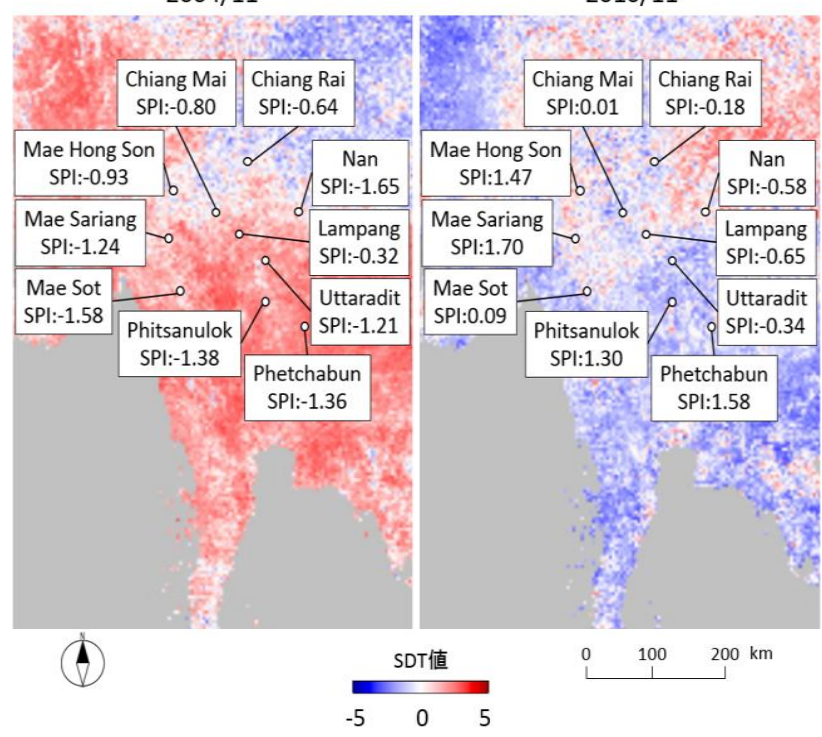

図-10 2004 年 11 月と 2010 年 11 月における SDT の空間分布

月SPIは負の相関が見られ，同一地点における年変動が うまく表されていることが確認できる。

(3) SDTマップ

2004年11月および2010年11月において算出したSDT マップを図-10に示す．なおSDTの算出に当たっては, 全ての地域に土地利用変化がないと仮定して数值化して いる. 例年と比較して，2004年の11月は降水量が不足し ており，2010年の11月は降水量が豊富な地域が多かった。 図-10から降水量が多い場合はSDTの值が小さい地域が 多く，降水量が少ない場合はSDTの值が大きい地域が多 いことが確認できる．また2010年11月の図より，SPI゙0.5以下であるNan とLampangではSDTの值が大きいこと が確認でき，空間変動がうまく表されていることがわか る.

\section{5. まとめ}

本研究では, 昼夜の地表面温度差に着目した干ばつ指 標（SDT）を提案した．さらにSDTの有用性を示すため に，タイ北部の10都市を対象として，既存の干ばつ指標 であるSPIとの関係性を評価した，その結果，乾季の始 まりである11月において，SDTはSPI同様の傾向を示し， 干ばつ指標として利用可能であることを提示できた。 ま たSDTの特徴である面的な評価が可能であることを活か し，SDTマップを作成し，空間変動がうまく表されてい ることを示した.

一方で，雨季の始まりである4月においては，SPI值か ら乾燥状態とされる場合に，SDTとSPIの相関が低く， SDTをSPIの代替指標として適用できないことが明らか となった．今後，SPIに限らず，土畩水分や農業生産量 への影響等との比較を行うことで，より実用的な干ばつ 指標としての改良が期待される.

謝辞 : 本研究で使用した地表面温度のデータは東京大学 生産技術研究所澤田義人特任研究員から提供された。本 研究は，国際協力機構と科学技術振興機構による「地球 規模課題対応国際科学技術協力プロジェクト」に採択さ れた「気候変動による水分野の適応策立案・実施支援シ ステムの構築」および環境省地球環境総合推進費（1E1104）の支援を受けて実施された。また本研究は科学研 究費補助金基盤研究(S)23226012の成果の一部である.

\section{参考文献}

1) Sergio M. Vicente-Serrano: Evaluating the Impact of Drought Using Remote Sensing in a Mediterranean, semi-arid Region, Natural Hazards, Volume 40, Issue 1，pp.173-208， 2007

2) Inge Sandholt, Kjeld Rasmussen, Jens Anderson: A simple interpretation of the surface temperature/vegetation index space fir assessment of surface moisture status, Remote sensing of Environment 79, pp.213-224, 2002

3) Z.Wan , P.Wang, X.Li: Using MODIS Land Surface Temperature and Normalized Difference Vegetation Index products for monitoring drought in the southern Great Plains, USA, International Journal of Remote Sensing, Vol.25, No.1, pp.61-72, 2004

4) Kalyanee Suwanprasert, Shinta Seto, Sudsaisin Kaewrueng: Intergrated Drought Risk Indices from Climate Based and Satellite Based Observation for Agriculture Drought Monitoring in Thailand, Annual Journal of Hydraulic Engineering, Vol.57, 2013

5）白岩立彦，中川博視，堀江武，松井勤，本間香貴：タイ稲 作の生産変動実態ならびに降雨量が生産変動に及ぼ寸影響, 地球環境, Vol.6, No.2, pp.207-215, 2002

6) C.T.Agnew: Using the SPI to Identify Drought, Drought Network News, Vol.12, No.1，2000

(2013. 9. 30受付) 